\title{
Trends in child sexual abuse research in Latin America and the Caribbean
}

\section{Tendencias en la investigación de abuso sexual infantil en América Latina y el Caribe}

Maribel Vega-Arce ${ }^{1}$, Gastón Núñez-Ulloa², Ignacia Sepúlveda-Ramírez ${ }^{1}$, Gonzalo Salas¹, Ivelisse Torres Fernandez ${ }^{3}$, Cristián Pinto-Cortez ${ }^{4}$

\section{ABSTRACT}

Introduction: Child sexual abuse (CSA) is an endemic threat to health. Although research on the subject has advanced considerably, there are few studies that have considered the perspectives of the region.

Objective: This study sought to analyze the research trends of CSA in Latin America and the Caribbean, emphasizing on its productivity as well as the evolution of the conceptual structure.

Method: For this study, a longitudinal bibliometric mapping of co-words in articles indexed in the Web of Science was conducted utilizing SciMAT. Results: Findings revealed an increase in the volume and impact of the articles published on this topic. The core corresponds to 35 articles, mostly quantitative, and published as part of international collaborations. The conceptual structure of the field addresses 19 topics with Maltreatment and Child Sexual Abuse; Risk Factors; and Family and Experiences considered as key themes; whereas Street Children and Emotional Abuse could be considered an emerging topic.

Conclusions: Findings suggest that although research focusing on CSA has been continuous and steady, a process of diversification on the topics of study within this field is emerging. Lastly, the scientific community could use the research findings to identify thematic areas of interest.

Keywords: child sexual abuse, psychosocial factors, bibliometrics, SciMAT, Latin America

\section{RESUMEN}

Introducción: El abuso sexual infantil (ASI) es una amenaza endémica para la salud. Aunque la investigación sobre el tema ha avanzado considerablemente, hay pocos estudios que hayan considerado las perspectivas regionales.

Objetivo: Este estudio buscó analizar las tendencias de la investigación del ASI en América Latina y el Caribe, haciendo énfasis en su productividad así como en la evolución de su estructura conceptual.

Método: Se realizó un mapeo bibliométrico longitudinal de las co-palabras de los artículos indexados en la Web of Science, utilizando SciMAT.

Resultados: Los hallazgos revelaron un aumento en el volumen y el impacto de los artículos publicados sobre este tema. El núcleo corresponde a 35 artículos, en su mayoría cuantitativos, publicados en el marco de colaboraciones internacionales. La estructura conceptual del campo aborda 19 temas Entre estos, Maltrato, Abuso Sexual Infantil, Factores de Riesgo, y Familia y Experiencias, son temas clave; mientras que Niños de la Calle y Maltrato Emocional podrían ser temas emergentes.

Conclusiones: Los resultados sugieren que, aunque la investigación centrada en el ASI ha sido continua y estable, está surgiendo un proceso de diversificación de sus temas de estudio. Por último, la comunidad científica podría utilizar estos resultados para identificar áreas temáticas de interés.

Palabras clave: abuso sexual infantil, factores psicosociales, bibliometría, SciMAT, América Latina

\footnotetext{
1 Universidad Católica del Maule, Talca, Chile

2 Universidad Autónoma de Chile, Talca, Chile

3 Carlos Albizu University, San Juan, Puerto Rico

4 Universidad de Tarapacá, Arica, Chile
}

Correspondence: Maribel Vega-Arce

Universidad Católica del Maule, Talca, Chile.

E-mail:mvega@ucm.cl

Received: 30 Aug 2018, Accepted: 25 Jun 2019

(C) 2019 by the authors; licensee Modestum Ltd., UK. This article is an open access article distributed under the terms and conditions of the Creative Commons Attribution License (http://creativecommons.org/licenses/by/4.0/). 


\section{INTRODUCTION}

Child sexual abuse has been reported in forensic $(1,2)$ and psychoanalytic publications (3) since the end of the 19th century. However, the 1970's observed an increase in research publications (4), as child sexual abuse was no longer considered an unusual phenomenon (5) but rather a public health issue of international relevance (6). Child sexual abuse is defined as a form of sexual violence (7) that implies "the involvement of a child in sexual activity that he or she does not fully comprehend, is unable to give informed consent to, or for which the child is not developmentally prepared, or else that violates the laws or social taboos of society" (p.10) (8). Currently, the global prevalence of child sexual abuse is estimated at $18 \%$ for girls and $7.6 \%$ for boys (9).

Child sexual abuse is considered a social determinant of health (10) that can impact both the physical (11) and mental (12) well-being of boys and girls throughout their life span. For children who have been poly-victimized $(13,14)$, its impact can be even more damaging. Furthermore, a history of child sexual abuse has been linked to smoking, severe obesity, depression as well as to others leading causes of death among adults, including ischemic heart disease, cancer, and liver disease (15).

The topic of child sexual abuse is a complex phenomenon (4), as such, research has played a key role in measuring (16) and understanding the scope and impact of child sexual abuse $(17,18)$. As previously stated research on child sexual abuse date from the 19th century; however, it is not until the middle of the 20th century that studies start to focus on the effects of child sexual abuse. In the 1970s, several descriptive studies were conducted and by the 1980s, explanatory models began to emerge (19), as well as the recognition of asymptomatic victims (20), male victims of child sexual abuse (21), and female perpetrators (22). From the 1990s to the present, a significant number of studies have focused on the analysis of mediating or moderating variables $(23,24)$ and the mechanisms by which poly-victimization exacerbate the harmful effects of child sexual abuse (23). Some authors, such as Briere and Elliot (25) and Pereda (26), point to this stage as a new generation of studies of child sexual abuse, mainly for its contribution to tertiary prevention (27).

However, despite the body of evidence accumulated throughout the decades, the way in which child sexual abuse is studied varies among researchers from different countries (28). This is because child sexual abuse is dependent on sociocultural variables (29) that not only impact the way in which it manifests in a given population (28), but also affects the way the topic is examined (30). Therefore, additional research is needed in order to better understand how the topic of child sexual abuse has been studied in other parts of the world. Of particular interest for this study, how child sexual abuse have been studied in Latin America and the Caribbean.

In Latin America, child sexual abuse is an endemic threat (31) than impact $13 \%$ of children in South America (32). Latin America and the Caribbean (LAC) is a region characterized by multiple cultural identities, with relatively heterogeneous living conditions. However, the region tends to share a social order that validates inequalities in power relations (33). In LAC, children represent $34.5 \%$ of the population (34) and constitute one of the groups against which violence has historically been perpetrated (35). The recognition of child sexual abuse and the sociocultural variables that help to perpetuate it (36), has resulted in the need for policy and research agendas that respond to local needs (37).

Child sexual abuse has been a focus of study in LAC for more than 20 years $(38,39)$. However, the research on this area has presented some challenges including the need to explore local definitions and socio-cultural dimensions; methodological issues; and the volume of production of scientific articles due to the disparities between LAC countries (33). In addition, to these challenges, the development and projections of child sexual abuse as a topic of study have not yet been researched. Therefore, the purpose of this study was to explore the research trends on child sexual abuse in Latin American and the Caribbean. Of particular interest was to examine the evolution of research topics between 20122017, indexed in the Web of Science Core Collection. Findings from this study could guide the development of research on child sexual abuse in the region by strengthening the relevant aspects of the local evolution of this area of study (40).

\section{MATERIALS AND METHODS}

For the purpose of this study a bibliometric trend analysis was conducted. Bibliometrics consists of the application of various statistical methods to quantify the scientific literature (41) in order to understand how research on certain topic has evolved over time (42). This type of study is referred as an ex post- facto historiographical investigation (43). Bibliometrics has been used to explore various topics in the area of health $(44,45)$ since it allow researchers to evaluate the development of a research topic as well as drawn projections through the dissemination of hidden patterns in the documenting systems that make up the articles (46). 


\section{Sampling Procedure}

The search for terms was conducted following the agreement adopted by the Interagency Working Group (47) for the understanding and use of different terms and concepts related to sexual violence against children, in particular, child sexual abuse. Therefore, the logarithm combined the terms "child", "children", "infancy", "boys", "girls", "sexual", "abuse", "incest", "rape", "molestation", "touching", "harassment" and "online", with Boolean operators. Inclusion criteria included: (a) research and review articles; (b) publication period between 1975 and 2017; and (c) published by authors with an affiliation name belonging to Latin America and the Caribbean. The identification of these countries was made considering the delimitations of the World Health Organization (WHO) and the Pan American Health Organization (48).

\section{Data Extraction}

For this study, data pertaining to child sexual abuse was retrieved from Web of Science (WoS) Core Collection, a bibliographic database belonging to Clarivate Analytics that covers nearly 2,700 titles in the scientific, engineering, medical, and social sciences. WoS was chosen because it has extensive journal coverage and a comparatively lower number of errors in recording the metadata used in bibliometrics (authorship, keywords, etc.) when compared to other existing catalogs (49). The relevance of each paper included was assessed through the expert judgment of two of the co-authors after reading the title, keywords, and abstract of each article to determine whether the inclusion criteria was met. Based on the inclusion criteria a total of 393 publications were found between 1992 and 2017.

\section{Data Analysis}

The documentary sample was analysed in three steps: (1) the characterization of the totality of the selected documents; (2) the identification of the highly cited articles; and (3) the mapping of the thematic evolution. For step one, the authors employed the automated tools available in the WoS to categorize the articles using the year of publication, journal, author(s), country, language, and citations received. Data was imported into the Microsoft Excel for analysis. Secondly, the most cited articles were identified by applying the concept of $\mathrm{H}$-Classics (50). $\mathrm{H}$-Classics enquiry the core of the most cited articles, which is delimited on the basis of cardinality between the number of citations and the value of the $\mathrm{H}$-Index (51) for the research area. These papers are considered classics since they are the most cited in the area; therefore, representing the main referents of this domain (50). Since the $\mathrm{H}$-Index for child sexual abuse was 35 ; that is, it has 35 articles that have been cited at least 35 times, these 35 papers constitute the core of the most cited (52) according to the $\mathrm{H}$-Classic. These articles were typified using the title, language, author (s), institutional affiliation, countries, journal and type of methodology used. The latter, according to the classification by Montero and León (43), differentiates between theoretical (classical and meta-analysis), quantitative, and qualitative articles.

Finally, a co-word analysis based on the article's keywords was conducted. This type of analysis focuses on the cooccurrence of certain datasets, such as authorship, citation, references, and topics covered, and seeks to bring out the plot that connects the documents (53). Keywords label papers based on the criteria of authors and/or editors (54), and are often utilized to study scientific trends on a variety of fields $(55,56)$ including health $(57,58)$. To perform this analysis, the data was imported into the SciMAT 1.1.04 (59), which allows the visualization of patterns and trends combined with indicators of quality (i.e., $\mathrm{H}$-index and number of citations) and performance (i.e., volume of articles published on the topic). For more information regarding SciMAT, please refer to Cobo et al. (2015) (60).

Using SciMAT 1.1.04, data was pre-processed (i.e., unifying plural and singular) and segmented by the years (19922017) in which the articles were published. Data was segmented into three time periods, with 10 years in the first two (1992-2001, 2002-2011) and 6 years in the last (2012-2017), due to the greater concentration of articles in recent years. Next, a co-occurrence analysis of keywords was conducted and a thematic network was generated based on the most central themes of each subset of themes or nodes. The thematic network was then normalized on the basis of the equivalence index (61) and its grouping and labelling was calculated by applying the algorithm of the simple centres (62). The Jaccard Index (63) and the Inclusion Index (64) were also employed to establish the overlap of keywords between the periods studied.

\section{Visualization Analyses}

In order to optimize the understanding of the analysis, five types of visualization analyses were conducted. First, using Microsoft Excel we graph the number of articles and citations per publication per year (Figure 1). Secondly, keywords were represented as a Tag Cloud (Figure 2), which provides a visual summary of the keywords frequency in the form of a weighted list (65). The Tag Cloud was generated through EdWordle, a visualization tool that encodes the frequency of 


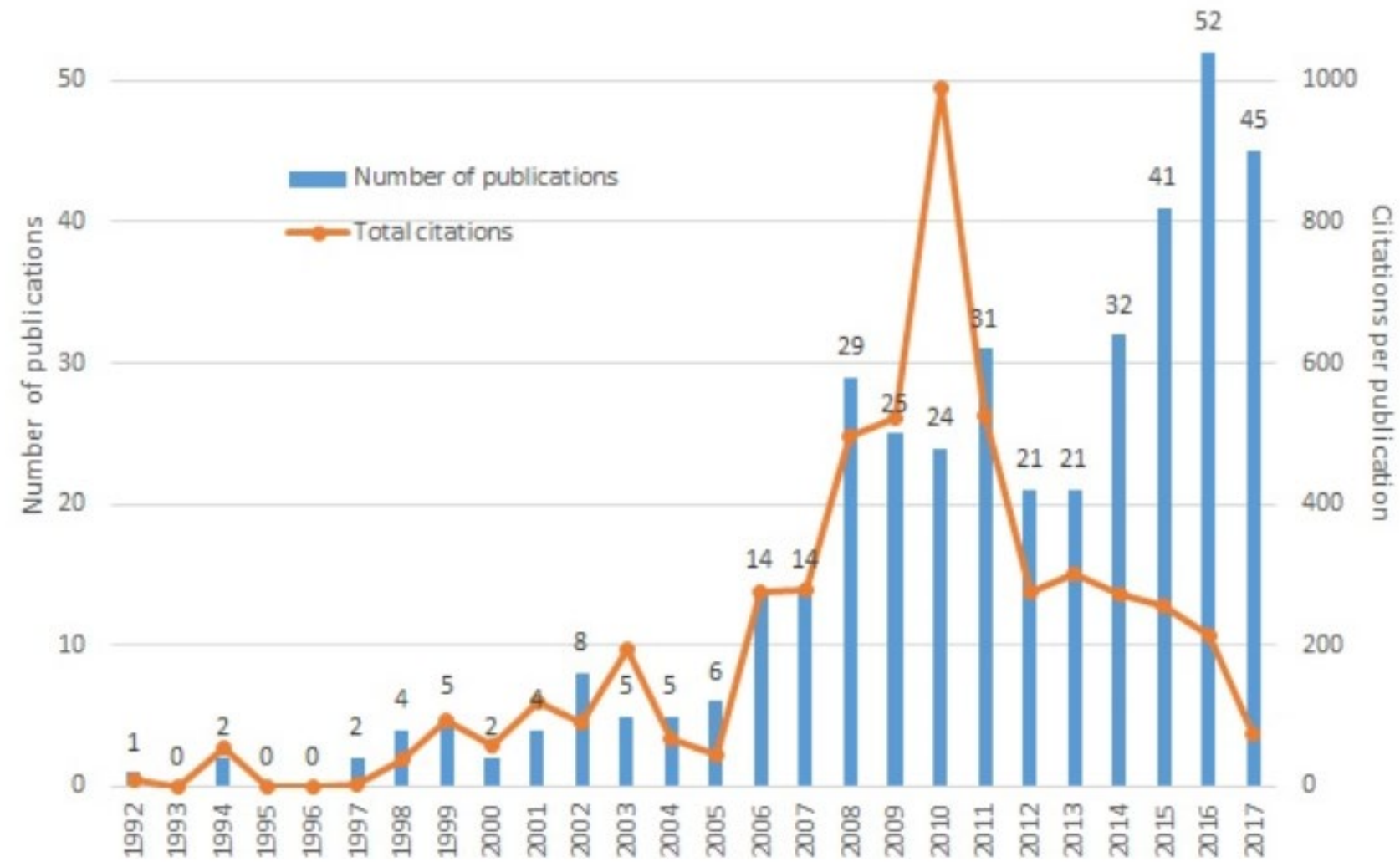

Figure 1: Number of articles and citation per publication by year

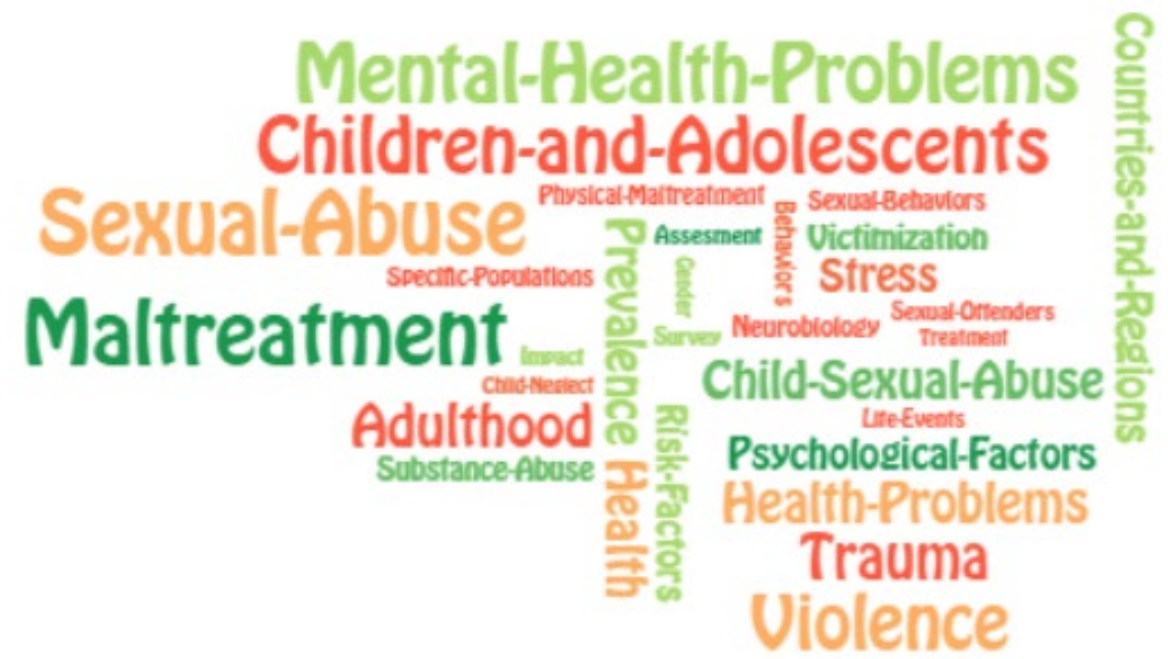

Figure 2: Tag Cloud of 30 main Keywords

occurrence of words (keywords) representing them in proportion to its size. This program also allowed us to preserve the order of the words throughout the editing process (66).

Third, a diagram of thematic stability between periods (Figure 3) was presented. In this figure, each circle represents a consecutive period in which the total number of keywords present is indicated. The horizontal dates detail the keywords shared by both periods and, in brackets, the stability reached between periods in an interval between 0 and 1 , with 0 being null stability and 1 as stable as possible (67). Lastly, the outgoing arrows accounts for the number of keywords from the previous period that were not present in the next one and the incoming arrows indicate those that are added in the subsequent period. 


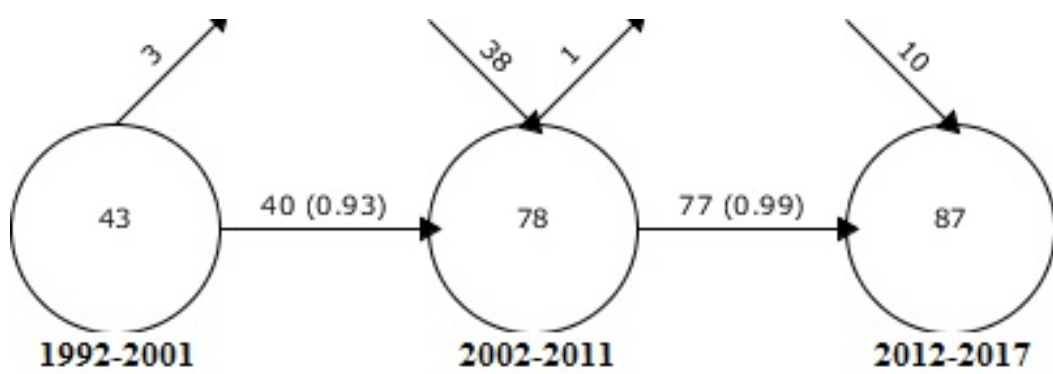

Figure 3: Thematic stability between periods of the child sexual abuse domain in Latin America and the Caribbean

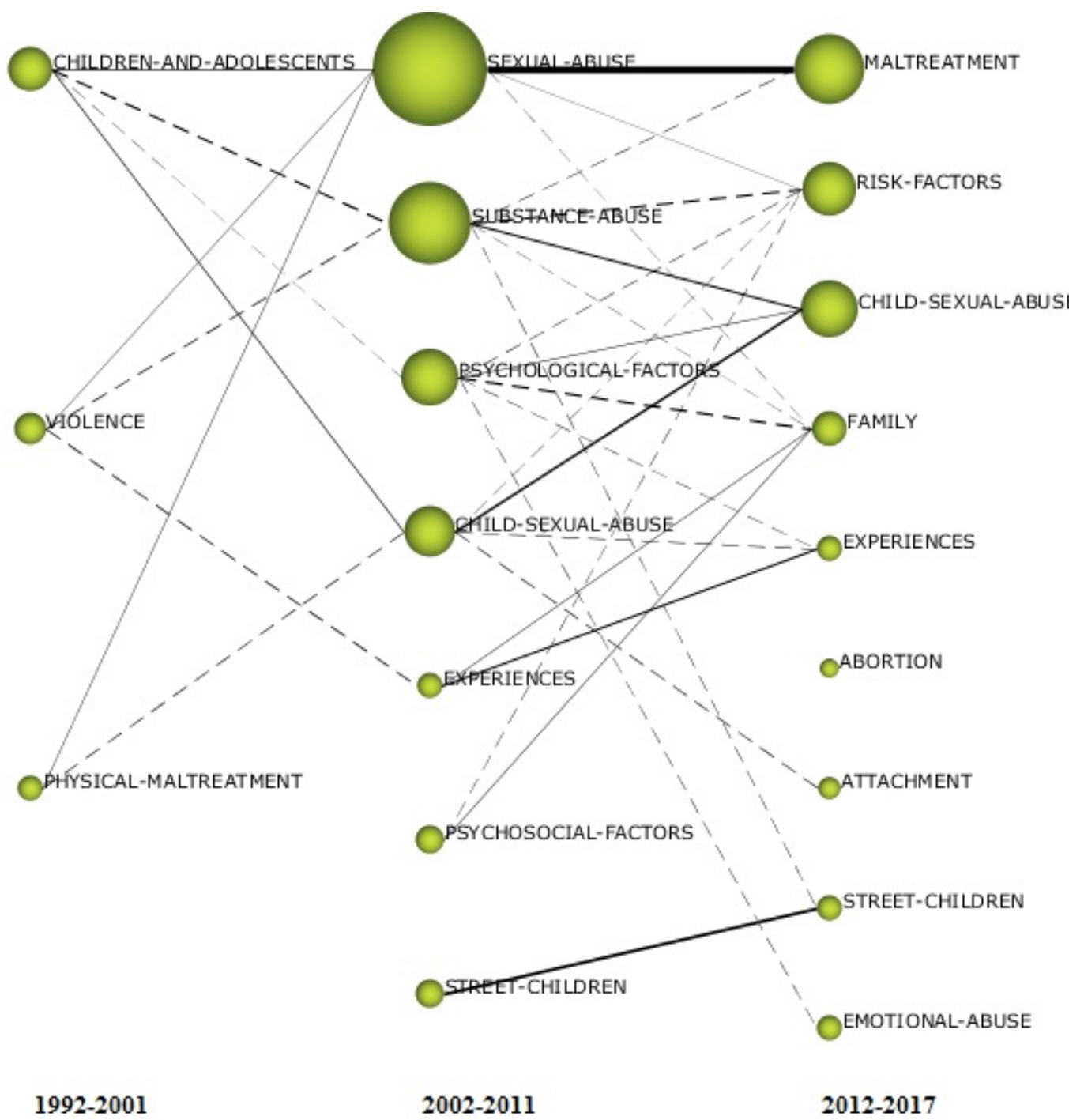

Figure 4: Conceptual evolution of the study of child sexual abuse in Latin America and the Caribbean, with volume proportional to the $\mathrm{H}$-Index

Forth, a thematic evolution map (Figure 4) was created. This map has a vertical axis that illustrates the three time periods studied, while the lines connect the evolution of the thematic network with a thickness proportional to the number of keywords that both themes have in common. The volume of the spheres is proportional to the value of the $\mathrm{H}$-Index for each theme.

Lastly, the themes for the 2012-2017 period were evaluated in relation to their centrality (which determines the intensity of their links with other themes) and density (which characterizes the strength of the links between terms that make up each node). The use of centrality and density as axes allows for the development of Strategic Diagrams (Figure 5) whose quadrants place the themes as (a) motors, (b) basic and transversal, (c) isolated, and (d) emerging or disappearing. Motor themes are highly developed and connected with other themes in the area. The basic and transversal 
Highly dereloped and isolated themes
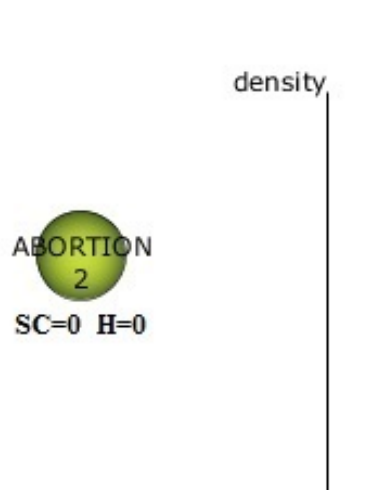

MALTREATMENT

180

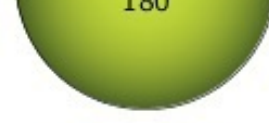

$\mathrm{SC}=1.229 \mathrm{H}=16$

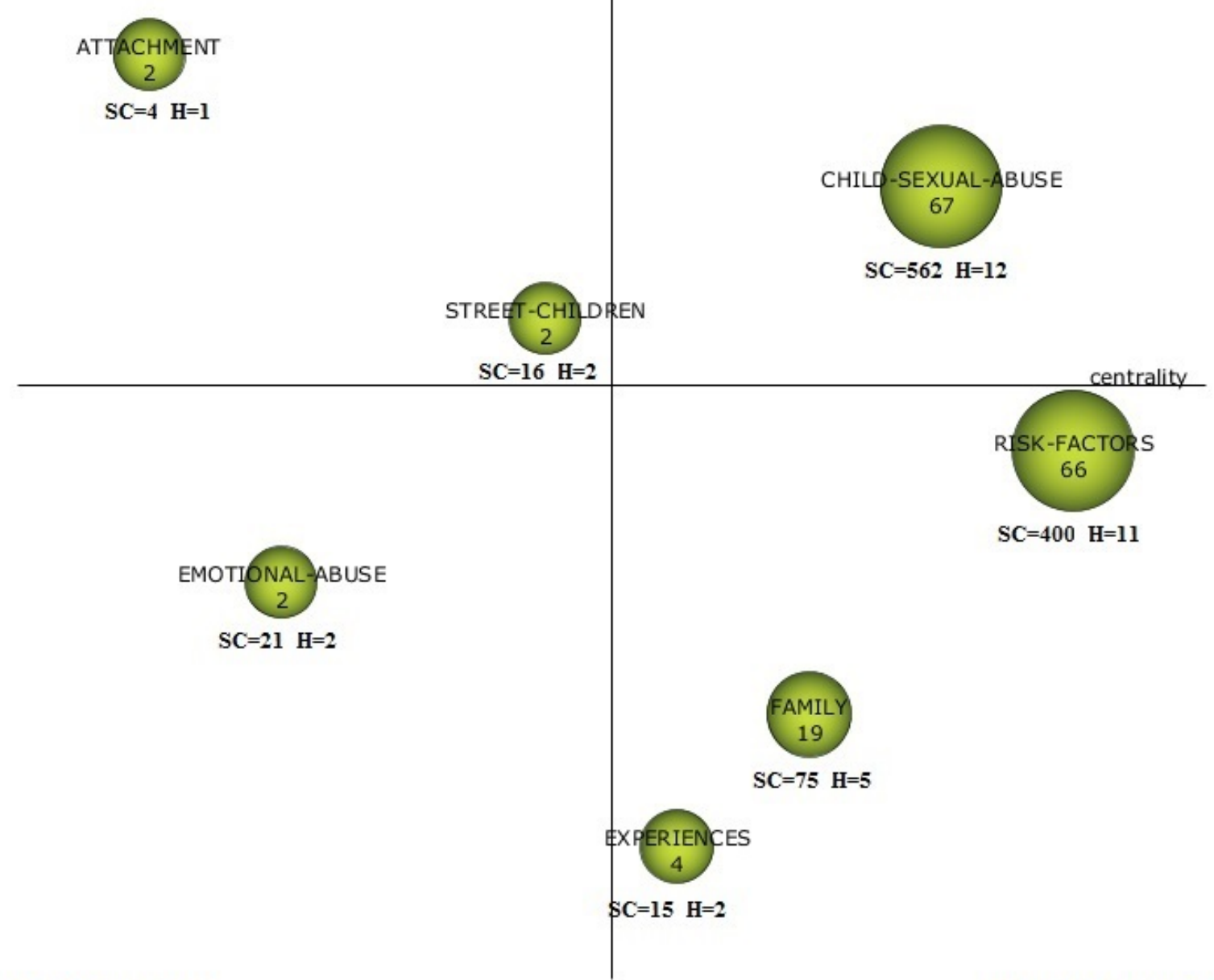

Basic and transversal themes

Emerging or declining themes

Note. $\mathrm{SC}=$ Sum Citation, $\mathrm{H}=\mathrm{H}-\mathrm{Index}$

Figure 5: Strategic diagram of the topics according to the number of documents in the period 2012-2017

themes are very linked in the area under study, but they still have a limited volume of documents that refer to them. Isolated topics are very specialized, so they have a high development, but few connections with other topics. Finally, emerging or disappearing topics correspond to the margins of the network (61).

\section{RESULTS}

Data indicates that child sexual abuse articles written by Latin American and Caribbean authors were published mostly in English (64.9\%), followed by Spanish (22.4\%), Portuguese (11.9\%), and French (0.76 \%). The journals with the highest number of published articles were Child Abuse and Neglect $(7.1 \% ; n=28)$; Mental Health $(6.9 \% ; n=27)$; and the Journal of Public Health $(3.6 \% ; n=14)$.

A total of 1,527 authors from 59 countries published the articles, reflecting the geographic diversity of the academic collaborations in the field. Latin American and Caribbean authors came from 14 countries, positioning Brazil and the southern cone as the region with the highest number of associated authors $(n=270)$. The countries with the highest number of articles published by were Brazil (27.2\%), Mexico (13.1\%) and Chile (5.3\%). According to their position in the 
Table 1: Search Terms

(child OR children OR childhood OR infancy OR boys OR girls) AND ((sexual AND abuse) OR incest OR rape OR molestation OR (sexual AND touching) OR (sexual AND harassment) OR online)

Table 2: Frequency distribution of the bibliometric parameters in H-Classics in three periods

\begin{tabular}{|c|c|c|c|}
\hline Parameters/Time period & 1992-2001 & 2002-2011 & 2012-2017 \\
\hline H-Classics, $n$ & 5 & 25 & 5 \\
\hline \multicolumn{4}{|l|}{ Language } \\
\hline English & 5 & 24 & 5 \\
\hline Portuguese & 0 & 1 & 0 \\
\hline Average of author(s) per article & 5,2 & 9,0 & 13,4 \\
\hline \multicolumn{4}{|l|}{ Type article } \\
\hline Cuantitative & 1 & 21 & 4 \\
\hline Cualitative & 4 & 0 & 0 \\
\hline Theoric articles & 0 & 4 & 1 \\
\hline \multicolumn{4}{|l|}{ Collaboration } \\
\hline International & 5 & 16 & 4 \\
\hline LAC & 0 & 0 & 0 \\
\hline National & 0 & 9 & 1 \\
\hline
\end{tabular}

total ranking of productivity by countries, they correspond respectively to the first, second and fourth countries with the highest number of authorship in published articles.

Lastly, article production was characterized by a relative increase in the number of documents indexed during the different time periods. For example, up to 2005 article production didn't exceed 10 articles per year; however, since 2014, every year more than 30 articles were published. Of interest, the first indexed article in 1992 "Violence and health: Preliminary elements for thought and action" (68) and two articles published in 1994 (38.69) included authors from Brazil. Figure 1 shows the number of articles and citations per publication by year.

\section{Highly Cited Papers}

The $\mathrm{H}$-Index for articles on child sexual abuse was 35, with 5,252 citations in total. The most frequently cited article was "Childhood adversities and adult psychopathology in the WHO World Mental Health Surveys" (70) with 503 citations, which is based on WHO surveys in 21 countries and include authors from Mexico, Colombia, and Brazil. The H-Classics articles were published between 1994 and 2016, with the largest number of classics published between 2002 and 2010 (see Table 1). H-Classics articles were published in 22 journals, from those three were published in Child Abuse and Neglect whereas the British Journal of Psychiatry, Journal of Adolescent Health, Psychological Medicine, Journal of Public and Social Health Science and Medicine, published two articles each. Almost all the articles were written in English (97\%; $n=34$ ), mainly in international collaboration scenarios (71) that bring together authors from countries other than Latin America and the Caribbean ( $71.4 \%$ documents), the remaining collaborations were between authors from the same country (20\% from Brazil and $8.6 \%$ from Mexico).

Over the periods studied, the number of authors in published papers progressively increased. On average, articles were written by nine authors distributed in a range between 3 and 34 authors. Of the 240 authors identified, $78.3 \%$ $(n=188)$ contributed one article; $13.8 \%(n=33)$ have two contributions; $4.6 \%(n=11)$ have three articles; and $3.3 \%(n=8)$ have four contributions. While in relatively low numbers, the LAC authors who published the most articles on child sexual abuse were José Posada-Villa $(n=4)$ from Colombia and Rodrigo Grassi-Oliveira $(n=4)$ from Brazil. Lastly, the majority of $\mathrm{H}$-Classics articles utilized quantitative methodologies $(74.3 \% ; n=26)$, followed by theoretical articles $(22.9 \% ; n=8)$ and one qualitative study (2.9\%).

\section{Research topics}

In total, 91 keyword groups were identified. The most frequent 30 keywords are shown in Figure 2. The most common terms were "Sexual Abuse" ( $n=165)$; "Mistreatment" $(n=163)$; and "Mental Health Problems" $(n=149)$. The analysis of keywords groups yielded the identification of 19 main topics in the three periods examined. The production and impact by theme is presented in Table 2. The number of topics, citations, and the $\mathrm{H}$-index for each topic evidenced the development and complexity of the research in the field. Similarly, topics that emerged in the last period, such as Attachment, are aligned with current trends and international relevance (72). 
Table 3: Performance measures for the themes by periods

\begin{tabular}{|c|c|c|c|}
\hline & \multicolumn{3}{|c|}{ Main documents } \\
\hline & $n$ & Total citations & H-Index \\
\hline \multicolumn{4}{|l|}{$1992-2001$} \\
\hline $\begin{array}{l}\text { Children-and-Adolescents } \\
\end{array}$ & 9 & 231 & 8 \\
\hline Violence & 4 & 68 & 4 \\
\hline $\begin{array}{l}\text { Physical-Maltreatment } \\
\end{array}$ & 2 & 33 & 2 \\
\hline \multicolumn{4}{|l|}{$2002-2011$} \\
\hline Sexual-Abuse & 135 & 3.091 & 30 \\
\hline Substance-Abuse & 58 & 1.835 & 20 \\
\hline $\begin{array}{l}\text { Psychological-Factors } \\
\end{array}$ & 29 & 671 & 12 \\
\hline Child-Sexual-Abuse & 18 & 383 & 10 \\
\hline Experiences & 3 & 16 & 2 \\
\hline Psychosocial-Factors & 4 & 82 & 3 \\
\hline Street-Children & 3 & 47 & 3 \\
\hline \multicolumn{4}{|l|}{$2012-2017$} \\
\hline Maltreatment & 180 & 1.229 & 16 \\
\hline Risk-Factors & 66 & 400 & 11 \\
\hline Child-Sexual-Abuse & 67 & 562 & 12 \\
\hline Family & 19 & 75 & 5 \\
\hline Abortion & 2 & 0 & 0 \\
\hline Experiences & 4 & 15 & 2 \\
\hline Attachment & 2 & 4 & 1 \\
\hline Street-Children & 2 & 16 & 2 \\
\hline Emotional-Abuse & 2 & 21 & 2 \\
\hline
\end{tabular}

\section{Evolution of research topics}

The evolution of the research topics was mapped considering the links between the main themes from the different periods. Figure 3 shows the stability range of keyword usage between consecutive time periods. As shown in Figure 3, the number of keywords increases progressively over the three periods, reaching its greatest diversity in 2012-2017. The overlap reached between periods is very high as manifested by the stability index of 0.93 between 1992-2001 and 20022011 and 0.98 between 2002-2011 and 2012-2017. This finding suggests that research production on child sexual abuse shows defined lines of development as evidenced by the very stable use of the same set of keywords to label articles over the years.

Furthermore, the field under study progressively increases the number of nodes ( 3 in the first period, 7 in the second, and 9 in the last period), which were maintained or transformed over time, adding new themes, as evidenced in Figure 4. This is the case of Psychological-Factors and Street-Children (2002-2011) and Abortion (2012-2017). It is important to note that although Psychological-Factors and Street-Children do not come directly from the previous period, they do remain prevalent in 2012-2017 through the use of terms such as Family and Risk Factors, and Street children, respectively.

This type of evolution generates a compact network of connections in which the 2012-2017 themes are part of a conceptual structure that has been enriched as the scientific field develops. Thus, Maltreatment (the theme with the greatest volume and impact in 2012-2017) is linked to the main themes of the previous periods: Sexual Abuse and Substance Abuse (2002-2011); and Children and Adolescents, Violence and Physical Maltreatment (1992-2001).

\section{Strategic diagram 2012-2017 period}

The Strategic Diagram for the 2012-2017 period is presented in Figure $\mathbf{5}$ and indicates the number of articles associated with each topic proportional to the number of documents as a measure of production. In addition, the impact of each of article is measured through the number of citations and the $\mathrm{H}$-Index. As shown in Figure 5, the themes for the 2012-2017 period are divided into the totality of the quadrants, showing different levels of development and integration with the other themes in the field. Maltreatment is the main motor of the area, presenting a high centrality and density, in addition to the greater volume of documents and impact of the period. The relevance of this topic is represented by citations and an $\mathrm{H}$-Index of 16 indicating that the articles are widely cited and could position themselves as reference documents in the field.

On the other hand, Child -Sexual -Abuse is positioned as the second motor in the area, with a centrality of 0,78 and density of 0,67 (both ranges on a scale between -1 and 1). As a central theme, Child-Sexual-Abuse is an issue that 
concentrates an important volume of research related to other main themes in the field and, at the same time, connected to each other. Lastly, Risk-Factors, Experiences, and Family are located as transversal themes whereas Abortion, Attachment, and Street-Child are currently isolated nuclei, with little relation to the other themes of the area; finally, Emotional-Abuse is a theme that emerges and may become consolidated as a nucleus of study within the child sexual abuse field or disappear.

\section{CONCLUSIONS}

This study presented the trends on child sexual abuse research conducted by Latin American and Caribbean authors between 1992 and 2017. The volume of articles published supports the notion that child sexual abuse is a relatively new domain of study in the region. When examining article production across different periods, an increase was observed with most articles published by authors from Brazil, Mexico, and Chile. The impact of these articles reached an $\mathrm{H}$-Index of 35, most of them written between 1994 and 2016, mostly as international collaborations and following a quantitative methodological approach.

The domain has 91 keyword groups with Sexual-Abuse, Maltreatment, and Mental-Health-Problems being the most frequent. These keywords were grouped into 19 themes that organize the conceptual structure of the field. Data also revealed that child sexual abuse has been studied since 1992. However, its evolution has been dense and stable, revealing changes in the centrality and density of the nodes, which accounts for an active development. Its active development facilitated the diversification of the field into nine topics from 2012-2017, which accounts for the largest volume of articles and keywords between the three periods.

The predominant theme in this last period is Maltreatment, a topic that conceptually integrates child sexual abuse as part of other types of violence directed toward children and Child-Sexual-Abuse, which specifically addresses the issues under study in the present investigation. Risk-Factors, Family and Experiences are considered basic and transversal themes, whereas Street-Children, Attachment and Abortion are isolated themes. Emotional-Abuse appears as an emergent theme. Even though the articles published between 2012 and 2017 have not reached the impact of the previous period, this might be due to the short time elapsed since their publications.

Overall, child sexual abuse is a recent research topic in the region, which volume of papers is relatively limited in comparison with other topics observed worldwide, such as child maltreatment (73) and traumatic stress (74). However, the production level in recent years suggests a process of dynamization that reorganizes its study nuclei and at the same time, rescues a trajectory of dense and stable research, which has shown a greater impact since 2002.

Findings of the study could assist the development of research that responds to regional needs such as prevention of child sexual abuse and its consequences; thus, contributing to the international body of knowledge on this subject. In addition, future research could focus on the factors that explain the differences in research productivity by country in particular, LAC authors. Furthermore, this study confirms previous findings that suggest that papers that have become referents in the field are collaborations that include LAC authors (76). This is an important point to consider in the promotion of collaborative networks. Lastly, topics of international relevance such as health (physical and mental) and neurobiology are frequently addressed in LAC, but are secondary to the topics that characterized the field.

Finally, several limitations are noted in this study. First, bibliometric trend analysis do not reveal the richness of the content of the articles nor assess its impact in areas other than academic, such as public policy or professional fields. Secondly, the data extraction conducted excluded articles that were not part of the Web of Science, which is a platform with geographical and linguistic bias, which can only explain part of the results (75). Lastly, child sexual abuse does not considered other forms of sexual violence that could be relevant to the region; thus limiting the number of articles that could have been included (76). Future research could address these limitations by conducting additional studies that integrate other databases such as Scopus, Ebsco, Pubmed, SciELO and Google Scholar as well as using data mining tools.

\section{Conflicts of Interest}

The authors declare that there is no conflict of interest related to this study.

\section{REFERENCES}

1. Tardieu A. Étude Médico-Légale Sur Les Attentats Aux Moeurs. Paris: J.B. Baillière et fils; 1867. 265 p.p.

2. Olafson E, Corwin DL, Summit RC. Modern history of child sexual abuse awareness: cycles of discovery and suppression. Child Abus Negl. 1993;17(1):7-24. https://doi.org/10.1016/0145-2134(93)90004-O 
3. Freud S. Infantile Sexuality. Three contributions to the sexual theory (A. Brill, Trans.). Journal of Nervous and Mental Disease Publishing Company. New York; 1910.

4. Mathews B, Collin-Vézina D. Child sexual abuse: toward a conceptual model and definition. Trauma Violence Abuse. 2017. [Epub ahead of print]. https://doi.org/10.1177/1524838017738726 PMid:29333990 PMCid:PMC6429628

5. Whittier N. The politics of child sexual abuse. Emotion, social movements, and the State. New York: Oxford University Press; 2009. 272 p.p.

6. Gilbert R, Widom CS, Browne K, Fergusson D, Webb E, Janson S. Burden and consequences of child maltreatment in high-income countries. Lancet. 2009;373(9657):68-81. https://doi.org/10.1016/S0140-6736(08)61706-7

7. UNICEF. Hidden in plain sight: A statistical analysis of violence against children. 2014 [online] [accessed 201901-09]. Available from: https://www.unicef.org/publications/files/Hidden_in_plain_sight_statistical_analysis_ Summary_SP_2_Sept_2014.pdf

8. World Health Organization, International Society for Prevention of Child Abuse and Neglect. Preventing child maltreatment: a guide to taking action and generating evidence. 2006 [online] [accessed 2019-01-09]. Available from: http://www.who.int/violence_injury_prevention/publications/violence/child_maltreatment/en/

9. Stoltenborgh $\mathrm{M}$, Bakermans-kranenburg MJ, Alink L, van ljzendoorn MH. The prevalence of child maltreatment across the globe: review of a series of meta-analysis. Child Abuse Rev. 2015;17(24):37-50. https://doi.org/10.1002/car.2353

10. Greenfield EA. Child abuse as a life-course social determinant of adult health. Maturitas. 2010;66(1):51-5. https://doi.org/10.1016/j.maturitas.2010.02.002 PMid:20207088

11. Widom CS, Czaja SJ, Bentley T, Johnson MS. A prospective investigation of physical health outcomes in abused and neglected children: new findings from a 30-year follow-up. Am J Public Health. 2012;102(6):1135-44. https://doi.org/10.2105/AJPH.2011.300636 PMid:22515854 PMCid:PMC3483964

12. Papalia NL, Luebbers S, Ogloff JR, Cutajar M, Mullen PE. The long-term co-occurrence of psychiatric illness and behavioral problems following child sexual abuse. Aust N Z J Psychiatry. 2017;51(6):604-13. https://doi.org/10.1177/0004867416667232 PMid:27630172

13. Turner HA, Shattuck A, Finkelhor D, Hamby S. Effects of poly-victimization on adolescent social support, selfconcept, and psychological distress. J Interpers Violence. 2017;32(5):755-80. https://doi.org/10.1177/0886260515586376 PMid:26033616

14. Finkelhor D, Shattuck A, Turner HA, Ormrod R, Hamby SL. Polyvictimization in developmental context. J Child Adolesc Trauma. 2011;4(4):291-300. https://doi.org/10.1080/19361521.2011.610432

15. Larkin H, Felitti VJ, Anda RF. Social work and adverse childhood experiences research: implications for practice and health policy. Soc Work Public Health. 2014;29(1):1-16. https://doi.org/10.1080/19371918.2011.619433 PMid:24188292

16. Barth J, Bermetz L, Heim E, Trelle E, Tonia T. The current prevalence of child sexual abuse worldwide: a systematic review and meta-analysis. Int J Public Health. 2013;58(3):469-83. https://doi.org/10.1007/s00038-012-0426-1 PMid:23178922

17. Fergusson DM, McLeod GF, Horwood L. Childhood sexual abuse and adult developmental outcomes: findings from a 30-year longitudinal study in New Zealand. Child Abuse Negl. 2013;37(9):664-74. https://doi.org/10.1016/j.chiabu.2013.03.013 PMid:23623446

18. Teicher $\mathrm{MH}$, Samson JA. Annual research review: enduring neurobiological effects of childhood abuse and neglect. J Child Psychol Psychiatry. 2016;57(3):241-66. https://doi.org/10.1111/jcpp.12507 PMid:26831814 PMCid:PMC4760853

19. Finkelhor D. A sourcebook on child sexual abuse. 1st ed. Los Angeles: SAGE Publications; 1986. 280 p. p.

20. Tong L, Oates K, McDowell M. Personality development following sexual abuse. Child Abuse Negl. 1987;11(3):371-83. https://doi.org/10.1016/0145-2134(87)90011-1

21. Browne A, Finkelhor D. Impact of child sexual abuse: a review of the research. Psychol Bull. 1986;99(1):66-77. https://doi.org/10.1037/0033-2909.99.1.66 PMid:3704036

22. Fritz GS, Wagner NN. A comparison of males and females who were sexually molested as children. J Sex Marital Ther. 1981;7(1):54-9. https://doi.org/10.1080/00926238108403440 PMid:7345149

23. Cecil CA, Viding E, Fearon P, Glaser D, McCrory EJ. Disentangling the mental health impact of childhood abuse and neglect. Child Abuse Negl. 2017;63:106-19. https://doi.org/10.1016/j.chiabu.2016.11.024 PMid:27914236 
24. Simon VA, Feiring C, Cleland CM. Early stigmatization, PTSD, and perceived negative reactions of others predict subsequent strategies for processing child sexual abuse. Psychol Violence. 2016;6(1):112-23. https://doi.org/10.1037/a0038264 PMid:28936363 PMCid:PMC5604874

25. Briere JN, Elliott DM. Immediate and long-term impacts of child sexual abuse. Future Child. 1994;4(2):54-69. https://doi.org/10.2307/1602523

26. Pereda N. Malestar psicológico en estudiantes universitarios víctimas de abuso sexual infantil y otros estresores [dissertation]. Barcelona: Universitat de Barcelona. Departament de Personalitat, Avaluació i Tractament Psicològic; 2006 [online] [accessed 2019-01-09]. Available from: http://hdl.handle.net/10803/2533

27. Roche DN, Runtz MG, Hunter MA. Adult attachment: a mediator between child sexual abuse and later $\begin{array}{llll}\text { psychological adjustment. J Interpers } & \text { Jiolence. }\end{array}$ https://doi.org/10.1177/088626099014002006

28. Wekerle C, Black T. Gendered violence: advancing evidence-informed research, practice and policy in addressing sex, gender, and child sexual abuse. Child Abuse Negl. 2017;66:166-70. https://doi.org/10.1016/j.chiabu.2017.03.010 PMid:28364956

29. Fontes LA, Plummer CA. Cultural issues in child sexual abuse: intervention and prevention. In: Goodyear-Brown, Paris, editor. Handbook of child sexual abuse: identification, assessment, and treatment. Hoboken, New Jersey: John Wiley \& Sons, Inc.; 2012. p. 487-508. https://doi.org/10.1002/9781118094822.ch22

30. Child Protection Monitoring and Evaluation Reference Group. UNICEF. Measuring violence against children: inventory and assessment of quantitative studies, Division of Data, Research and Policy, New York; 2014 [online] [accessed 2019-01-09]. Available from: https://data.unicef.org/wp-content/uploads/2014/11/MeasuringViolence-against-Children-\%E2\%80\%93-Inventory-and-assessment-of-quantitative-studies.pdf

31. Veenema TG, Thornton CP, Corley A. The public health crisis of child sexual abuse in low and middle income countries: an integrative review of the literature. Int J Nurs Stud. 2015;52(4):864-81. https://doi.org/10.1016/j.ijnurstu.2014.10.017 PMid:25557553

32. Stoltenborgh M, van IJzendoorn MH, Euser EM, Bakermans-Kranenburg MJ. A global perspective on child sexual abuse: meta-analysis of prevalence around the world. Child Maltreat. 2011;16(2):79-101. https://doi.org/10.1177/1077559511403920 PMid:21511741

33. Contreras JM, Bott S, Guedes A, Dartnall E. Violencia sexual en Latinoamérica y el Caribe: análisis de datos secundarios. Iniciativa de Investigación sobre la Violencia Sexual. 2010.

34. Céspedes $C$, Robles $C$. Niñas y adolescentes en américa latina y el caribe: deudas de igualdad. Serie Asuntos de Género n 133 Santiago: Naciones Unidas; 2016. 100 p. p.

35. Castillo-Gallardo P. Desigualdad e infancia: lectura crítica de la historia de la infancia en Chile y en América Latina. Rev Latinoam Cienc Soc Niñez Juv. 2015;13(1):97-109. https://doi.org/10.11600/1692715x.1314030214

36. Wirtz AL, Alvarez C, Guedes AC, Brumana L, Modvar C, Glass N. Violence against children in Latin America and Caribbean countries: a comprehensive review of national health sector efforts in prevention and response. BMC Public Health. 2016;16(1):1006. https://doi.org/10.1186/s12889-016-3562-3 PMid:27659869 PMCid:PMC5034460

37. Ardila-Gómez S, Lugo-Palacios DG, Vargas-Palacios E. Conectando la investigación y las políticas en América Latina y el Caribe: el caso de la violencia. Glob Health Promot. 2015;22(1):97-9. https://doi.org/10.1177/1757975914566156

38. Kornblit A. Domestic violence: an emerging health issue. Soc Sci Med. 1994;39(9):1181-8. https://doi.org/10.1016/0277-9536(94)90350-6

39. Amazarray MR, Koller SH. Alguns aspectos observados no desenvolvimento de crianças vítimas de abuso sexual. Psicol Refle Crit. 1998;11(3):559-78. https://doi.org/10.1590/S0102-79721998000300014

40. Luke DA, Sarli CC, Suiter AM, et al. The translational science benefits model: a new framework for assessing the health and societal benefits of clinical and translational sciences. Clin Transl Sci. 2018;11(1):77-84. https://doi.org/10.1111/cts.12495 PMid:28887873 PMCid:PMC5759746

41. Pritchard A. Statistical bibliography or bibliometrics? J Doc. 1969;25(4):348-9.

42. Garfield E. Scientography: mapping the tracks of science. Curr Contents Soc Behav Sci. 1994;7(45):5-10.

43. Montero I, León OG. A guide for naming research studies in Psychology. Int J Clin Health Psychol. 2007;7(3):84762. 
44. Catalá-López F, Alonso-Arroyo A, Page MJ, Hutton B, Tabarés-Seisdedos R, Aleixandre-Benavent R. Mapping of global scientific research in comorbidity and multimorbidity: a cross-sectional analysis. PLoS One. 2018;13(1):e0189091. https://doi.org/10.1371/journal.pone.0189091 PMid:29298301 PMCid:PMC5751979

45. Chinchilla-Rodríguez Z, Zacca-González G, Vargas-Quesada B, Moya-Anegón F. Latin American scientific output in public health: combined analysis using bibliometric, socioeconomic and health indicators. Scientometrics. 2015;102(1):609-28. https://doi.org/10.1007/s11192-014-1349-9

46. Gutiérrez-Salcedo M, Martínez MÁ, Moral-Munoz JA, Herrera-Viedma E, Cobo MJ. Some bibliometric procedures for analyzing and evaluating research fields. Appl Intell. 2018;48(5):1275-87. https://doi.org/10.1007/s10489017-1105-y

47. Greijer S, Doek J. Terminology guidelines for the protection of children from sexual exploitation and sexual abuse [online]. Luxenburg; 2016. Available from: http://luxembourgguidelines.org/english-version/ [accessed 2019-0618].

48. Organización Panamericana de la Salud/Organización Mundial de la Salud. Indicadores básicos. Situación de salud en las Américas [online]. 2017 [accessed 2019-06-18]. Available from: http://iris.paho.org/xmlui/bitstream/handle/123456789/34330/IndBrasicos2017_spa.pdf?sequence=1\&isAllowe d=y\%0Ahttps://web.observatorio.co/publicaciones/indicadores_basicos_de_salud_2017.pdf

49. Gomez-Jauregui V, Gomez-Jauregui C, Manchado C, Otero C. Information management and improvement of citation indices. Int J Inf Manage. 2014;34(2):257-71. https://doi.org/10.1016/j.ijinfomgt.2014.01.002

50. Martínez MA, Herrera M, López-Gijón J, Herrera-Viedma E. H-Classics: Characterizing the concept of citation classics through H-index. Scientometrics. 2014;98(3):1971-83. https://doi.org/10.1007/s11192-013-1155-9

51. Hirsch JE. An index to quantify an individual's scientific research output. Proc Natl Acad Sci U S A. 2005;102(46):16569-72. https://doi.org/10.1073/pnas.0507655102 PMid:16275915 PMCid:PMC1283832

52. Rousseau R. New developments related to the Hirsch index [online]. 2006 [accessed 2019-02-12]. Available from: http://eprints.rclis.org/archive/00006376/

53. van Eck NJ, Waltman L. Visualizing Bibliometric Networks. In: Ding Y, Rousseau R, Wolfram D, editors. Measuring Scholarly Impact. Cham: Springer; 2014. p. 285-320. https://doi.org/10.1007/978-3-319-10377-8_13

54. Radhakrishnan S, Erbis S, Isaacs JA, Kamarthi S. Novel keyword co-occurrence network-based methods to foster systematic reviews of scientific literature. PLoS One. 2017;12(3):e0172778. https://doi.org/10.1371/journal.pone.0172778 PMid:28328983 PMCid:PMC5362196

55. Li M. An exploration to visualise the emerging trends of technology foresight based on an improved technique of co-word analysis and relevant literature data of WOS. Technol Anal Strateg. 2017;29(6):655-71. https://doi.org/10.1080/09537325.2016.1220518

56. Topalli M, Ivanaj S. Mapping the evolution of the impact of economic transition on Central and Eastern European enterprises: a co-word analysis. J World Bus. 2016;51(5):744-59. https://doi.org/10.1016/j.jwb.2016.06.003

57. Hong $Y$, Yao Q, Yang $Y$, et al. Knowledge structure and theme trends analysis on general practitioner research: a co-word perspective. BMC Fam Pract. 2016;17:10. https://doi.org/10.1186/s12875-016-0403-5 PMid:26831329 PMCid:PMC4734860

58. Shen L, Xiong B, Li W, Lan F, Evans R, Zhang W. Visualizing collaboration characteristics and topic burst on international mobile health research: bibliometric analysis. JMIR Mhealth Uhealth. 2018;6(6):e135. https://doi.org/10.2196/mhealth.9581 PMid:29871851 PMCid:PMC6008511

59. Cobo MJ, López-Herrera AG, Herrera-Viedma E, Herrera F. SciMAT: a new science mapping analysis software tool. J Am Soc Inf Sci Technol. 2012;63(8):1609-30. https://doi.org/10.1002/asi.22688

60. Cobo MJ, López-Herrera AG, Herrera-Viedma E. A relational database model for science mapping analysis. Acta Polytech Hung. 2015;12(6):43-62. https://doi.org/10.12700/APH.12.6.2015.6.3

61. Callon M, Courtial JP, Laville F. Co-word analysis as a tool for describing the network of interactions between basic and technological research: the case of polymer chemsitry. Scientometrics. 1991;22(1):155-205. https://doi.org/10.1007/BF02019280

62. Coulter N, Monarch I, Konda S. Software engineering as seen through its research literature: a study in co word analysis. J Assoc Inf Sci Technol. 1998;49(13):1206-23. https://doi.org/10.1002/(SICI)10974571(1998)49:13<1206::AID-ASI7>3.0.CO;2-F

63. Jaccard P. Distribution de la flore alpine dans le Bassin des Drouces et dans quelques regions voisines. Bull Soc Vaud Sci Nat. 1901;37(140):241-72. 
64. Sternitzke $C$, Bergmann I. Similarity measures for document mapping: a comparative study on the level of an individual scientist. Scientometrics. 2009;78(1):113-30. https://doi.org/10.1007/s11192-007-1961-z

65. Sinclair J, Cardew-Hall M. The folksonomy tag cloud: when is it useful? J Inf Sci. 2008;34(1):15-29. https://doi.org/10.1177/0165551506078083

66. Wang Y, Chu X, Bao C, et al. EdWordle: consistency-preserving word cloud editing. IEEE Trans Vis Comput Graph. 2018;24(1):647-56. https://doi.org/10.1109/TVCG.2017.2745859 PMid:28866587

67. Small HG. A co-citation model of a scientific specialty: a longitudinal study of collagen research. Soc Stud Sci.1977;7(2):139-66. https://doi.org/10.1177/030631277700700202

68. Franco Agudelo. Violence and health: preliminary elements for thought and action. Int J Heal Serv. 1992;22(2):365-76. https://doi.org/10.2190/XE4A-NBNQ-EQ3B-66C5 PMid:1601553

69. Pope HG Jr, Mangweth B, Negrão AB, Hudson JI, Cordás TA. Childhood sexual abuse and bulimia nervosa: a comparison of American, Austrian, and Brazilian women. Am J Psychiatry. 1994;151(5):732-7. https://doi.org/10.1176/ajp.151.5.732 PMid:8166316

70. Kessler RC, Mclaughlin KA, Green JG, et al. Childhood adversities and adult psychopathology in the WHO World Mental Health Surveys. Br J Psychiatry. 2010;197(5):378-85. https://doi.org/10.1192/bjp.bp.110.080499 PMid:21037215 PMCid:PMC2966503

71. Subramanyam K. Bibliometric studies of research collaboration: a review. J Inf Sci. 1983;6(1):33-8. https://doi.org/10.1177/016555158300600105

72. Seto MC, Babchishin KM, Pullman LE, McPhail IV. The puzzle of intrafamilial child sexual abuse: a meta-analysis comparing intrafamilial and extrafamilial offenders with child victims. Clin Psychol Rev. 2015;39:42-57. https://doi.org/10.1016/j.cpr.2015.04.001 PMid:25935749

73. Tran BX, Pham TV, $\mathrm{Ha} \mathrm{GH}$, et al. A bibliometric analysis of the global research trend in child maltreatment. Int J Environ Res Public Health. 2018;15(7). pii: E1456. https://doi.org/10.3390/ijerph15071456 PMid:29996540 PMCid:PMC6069266

74. Fodor KE, Unterhitzenberger J, Chou CY, et al. Is traumatic stress research global? A bibliometric analysis. Eur J Psychotraumatol. 2014;5(1). https://doi.org/10.3402/ejpt.v5.23269 PMid:24563730 PMCid:PMC3930940

75. Mongeon P, Paul-Hus A. The journal coverage of Web of Science and Scopus: a comparative analysis. Scientometrics. 2016;106(1):213-28. https://doi.org/10.1007/s11192-015-1765-5

76. Castilho CT, Evrard B, Charrier D. Child sex tourism in the context of the 2014 FIFA Football World Cup: the case of the host city of Recife, Brazil. Sport Soc. 2018;21(3):497-515. https://doi.org/10.1080/17430437.2017.1346623

$\diamond \diamond \diamond \diamond \diamond \diamond \diamond$

http://www.ejgm.co.uk 